Article

\title{
Plasma-Catalysis for Volatile Organic Compounds Decomposition: Complexity of the Reaction Pathways during Acetaldehyde Removal
}

\author{
Arlette Vega-González * , Xavier Duten and Sonia Sauce \\ CNRS, UPR 3407, Laboratoire des Sciences des Procédés et des Matériaux, LSPM, Université Sorbonne Paris \\ Nord, F-93430 Villetaneuse, France; xavier.duten@lspm.cnrs.fr (X.D.); sauce.sonia@gmail.com (S.S.) \\ * Correspondence: arlette.vega@lspm.cnrs.fr; Tel.: +33-1-49-40-34-31
}

Received: 4 September 2020; Accepted: 30 September 2020; Published: 3 October 2020

\begin{abstract}
Acetaldehyde removal was carried out using non-thermal plasma (NTP) at $150 \mathrm{~J} \cdot \mathrm{L}^{-1}$, and plasma-driven catalysis (PDC) using $\mathrm{Ag} / \mathrm{TiO}_{2} / \mathrm{SiO}_{2}$, at three different input energies-70, 350 and $1150 \mathrm{~J} \cdot \mathrm{L}^{-1}$. For the experimental configuration used, the PDC process showed better results in acetaldehyde $\left(\mathrm{CH}_{3} \mathrm{CHO}\right)$ degradation. At the exit of the reactor, for both processes and for all the used energies, the same intermediates in $\mathrm{CH}_{3} \mathrm{CHO}$ decomposition were identified, except for acetone which was only produced in the PDC process. In order to contribute to a better understanding of the synergistic effect between the plasma and the catalyst, acetaldehyde/catalyst surface interactions were studied by diffuse-reflectance infrared Fourier transform spectroscopy (DRIFTS). These measurements showed that different species such as acetate, formate, methoxy, ethoxy and formaldehyde are present on the surface, once it has been in contact with the plasma. A reaction pathway for $\mathrm{CH}_{3} \mathrm{CHO}$ degradation is proposed taking into account all the identified compounds in both the gas phase and the catalyst surface. It is very likely that in $\mathrm{CH}_{3} \mathrm{CHO}$ degradation the presence of methanol, one of the intermediates, combined with oxygen activation by silver atoms on the surface, are key elements in the performance of the PDC process.
\end{abstract}

Keywords: non-thermal plasma; catalysis; VOC; DRIFTS; acetaldehyde

\section{Introduction}

Diphasic processes combining a non-thermal plasma at atmospheric pressure and a catalytic bed have become of major interest for air-pollutant removal, and particularly volatile organic compounds (VOC) [1-3]. Indeed, compared to classical air cleaning techniques (thermal catalysis or photocatalysis), plasma-driven catalysis can lead to similar or better VOC degradation rates with less energy injected into the reactor and without catalyst deactivation issues [4,5]. Moreover, in the case of indoor air cleaning, where low VOC concentrations (in the ppm order) have to be removed, this diphasic process seems to be the most suitable [6]. Reviews dealing with the synergistic effects and mechanism of a non-thermal plasma catalysis system in volatile organic compound removal have recently been published [7-9]. Among the studies dealing with the different aspects of such a complex process, we can mention studies on plasma/pollutant interactions [10], surface charging [11,12], adsorption [13,14] or catalyst activation by non-thermal plasma (NTP) [15].

Given the fact that the induced heterogeneous reactions and the plasma are interdependent due to the plasma's continuous discharge during processing, it is essential to make further progress on identifying the surface species forming on the catalyst under the plasma effect. The in-situ Fourier transformed infrared spectroscopy (FTIR)/diffuse-reflectance infrared Fourier transform spectroscopy (DRIFTS) approach for studying catalysts under working conditions is gaining importance in the 
framework of the plasma-driven catalysis (PDC) process. To our knowledge, the first of these studies was carried out on isopropanol conversion on $\gamma-\mathrm{Al}_{2} \mathrm{O}_{3}$ [16]. The authors used a dielectric barrier discharge (DBD) plasma reactor, under static conditions, coupled to in-situ FTIR spectroscopy. They were able to show that unlike the thermal catalysis pathway, with the DBD process the first reaction intermediate is acetone. Plasma-assisted hydrocarbon selective catalytic reduction [17], catalytic steam-reforming of methane [18], reverse water-gas [19]/water-gas shift [20] and plasma-assisted $\mathrm{CO}_{2}$ hydrogenation [21] processes have also been studied using in-situ DRIFTS. These works pointed out the fact that NTP is able to activate some of the species present either in the gas phase or on the surface, thus improving the performance of the PDC process. Indeed, the role of oxygen in the PDC process has been investigated via isotopically-labeled molecular oxygen $\left({ }^{18} \mathrm{O}_{2}\right)$; the results showed that oxygen was fixed onto the surface of the catalyst by the action of the NTP discharge, and was able to survive in such a state for about $30 \mathrm{~min}$ [22]. What is more, this same study demonstrated that when using Ag nanoparticles supported on catalysts, they served as oxygen reservoirs. As for VOC removal with non-thermal plasma-assisted catalysis, isopropanol [23,24], toluene [24,25] and acetone removal [26] have been studied using an FTIR in-situ technique. This approach allowed the identification of reaction intermediates, and the following of the evolution of secondary compounds arising from the VOC oxidation.

In a previous work [27] we have showed that, by combining a DBD generated at atmospheric pressure and a silver-supported nanostructured catalyst, acetaldehyde can be removed up to $98 \%$ with the production of mainly $\mathrm{CO}, \mathrm{CO}_{2}$ and $\mathrm{O}_{3}$. In addition, we have also studied acetaldehyde adsorption and ozonation over the same silver-based catalyst, and the obtained results support the fact that PDC is a rather complex process in which homogeneous and heterogeneous chemistry are closely interconnected [28]. In the present study we analyse the changes that occurred on an $\mathrm{Ag} / \mathrm{TiO}{ }_{2} / \mathrm{SiO}_{2}$ catalyst, used for acetaldehyde removal, after plasma exposure. We investigate which intermediate species were formed on the surface after acetaldehyde adsorption and discharge-assisted conversion by using DRIFT spectroscopy. Gaseous by-products resulting from this process were monitored and quantified, with the aim to contribute to a better understanding of the mechanism of acetaldehyde oxidation. Essentially based on the reactor outlet analysis, the surface composition and literature data, an acetaldehyde removal pathway is proposed considering both the homogeneous and heterogeneous chemistry of the process.

\section{Results}

The results obtained when studying acetaldehyde removal using non-thermal plasma, NTP-plasma driven catalysis or just a catalyst will be briefly presented. In addition, we have previously shown that VOC adsorption and heterogeneous NTP-induced chemistry have to be taken into account when associating NTP in air with a catalyst. These results, discussed in more detail in previous works [27-29], were obtained at ambient temperature and atmospheric pressure, but in different configurations of the plasma discharge (i.e., corona or DBD discharge, diameter of the catalyst support, mass of catalyst, energy injected).

\subsection{Acetaldehyde Decomposition Using the Plasma-Driven Catalysis Process}

The results obtained for acetaldehyde decomposition with the single stage plasma-driven catalysis, and the plasma-alone processes are presented in Table 1. It is worth noting that the degradation of acetaldehyde by the catalyst alone in the DBD reactor was also studied at room temperature and atmospheric pressure. In this case, neither any degradation of acetaldehyde nor by-product formation is observed.

As can be seen from the results presented in the table above, at atmospheric pressure and ambient temperature the catalyst is not active for acetaldehyde removal. With the plasma-alone process acetaldehyde can be removed up to $55 \%$ with an energy consumption of $150 \mathrm{~J} \cdot \mathrm{L}^{-1}(\sim 250 \mathrm{~mW}$ power consumption). As soon as the silver nanostructured catalyst is introduced into the discharge zone, 
acetaldehyde removal increases, already allowing, at $70 \mathrm{~J} \cdot \mathrm{L}^{-1}(\sim 120 \mathrm{~mW}), 33 \%$ to be obtained and up to $98 \%$ at $1150 \mathrm{~J} \cdot \mathrm{L}^{-1}(\sim 2 \mathrm{~mW})$.

Table 1. Acetaldehyde removal obtained using the plasma-driven catalysis and the non-thermal plasma (NTP) processes.

\begin{tabular}{cccccc}
\hline \multirow{2}{*}{$\begin{array}{c}\text { Specific Input Energy } \\
\text { (SIE) (J.L L }\end{array}$} & $\mathrm{Ag} / \mathrm{TiO}_{2} / \mathrm{SiO}_{2}$ & Plasma Alone & \multicolumn{3}{c}{ Plasma $+\mathrm{Ag} / \mathrm{TiO}_{2} / \mathrm{SiO}_{2}$} \\
\cline { 2 - 6 } & Alone & $\mathbf{1 5 0}$ & $\mathbf{7 0}$ & 350 & $\mathbf{1 1 5 0}$ \\
\hline Acetaldehyde removal (\%) & 0 & 55 & 33 & 87 & 98 \\
\hline
\end{tabular}

The main gaseous by-products at the exit of the DBD reactor are $\mathrm{CO}$ and $\mathrm{CO}_{2}$, but other organic by-products have also been identified: methanol (Me), acetic acid (AcA), acetone (Ace), methyl formate $(\mathrm{MeF})$, methyl acetate $(\mathrm{MeA})$, 1,2-ethanediol monoformate $(\mathrm{EmF}), 1,2$-ethanediol diformate (EdF), nitromethane $(\mathrm{Nm})$, methyl nitrate $(\mathrm{MN})$ and 2-ethoxyethanol (Eet). Their distribution at the DBD reactor exit is presented in Figure 1, except for the ones present in trace amounts (Eet), or those that could not be quantified (MN). Among these organic products we recognize compounds belonging to different functional groups such as hydroxyl, carboxyl, carbonyl, carboalkoxy and nitro compounds, reflecting the complexity of the chemistry involved in such processes.
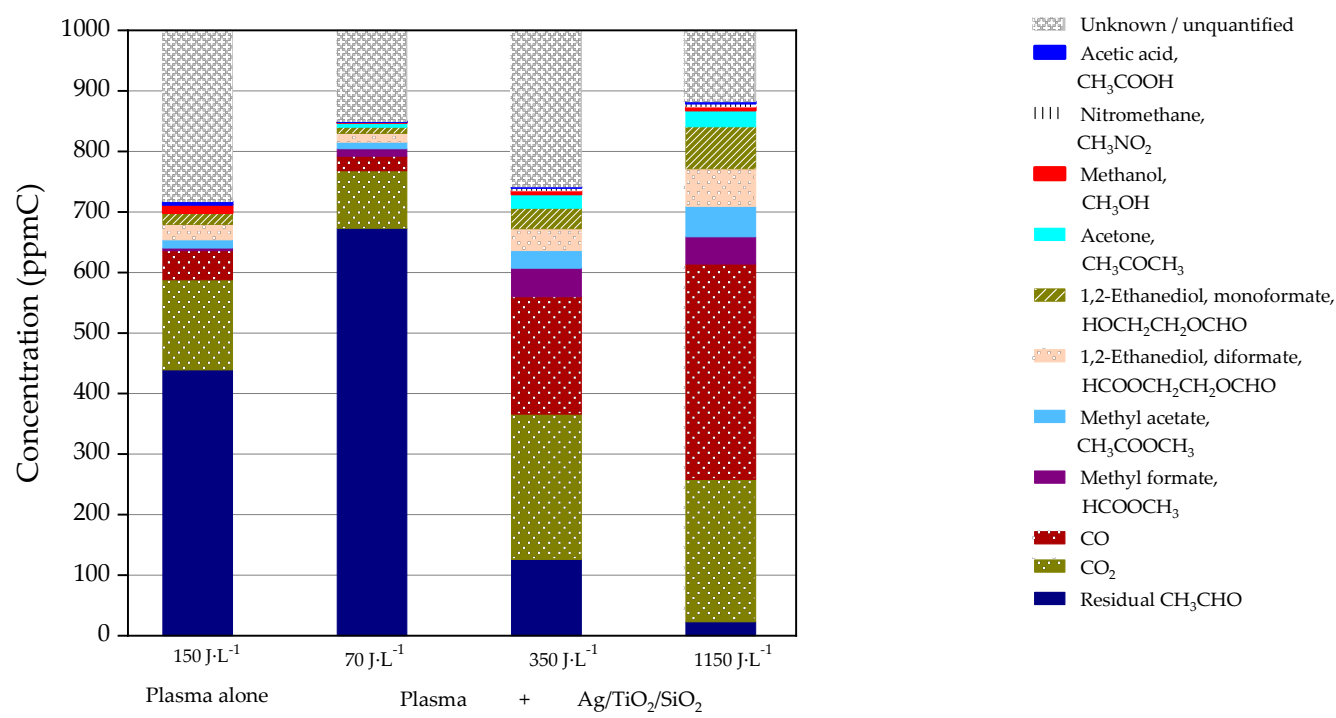

Figure 1. Comparison of the composition of the dielectric barrier discharge (DBD) reactor effluent obtained with the plasma-alone and the plasma-driven catalysis process, as a function of SIE.

From the obtained results we can say that with the plasma-alone process neither acetone nor nitromethane are produced at $150 \mathrm{~J} \cdot \mathrm{L}^{-1}$; and compared with the PDC process, more acetic acid and methanol are formed. With the PDC process at $70 \mathrm{~J} \cdot \mathrm{L}$, aside from methyl formate and the emergence of acetone, all the other by-products are produced in lower amounts compared with NTP alone, which is certainly due to the lower acetaldehyde conversion. The by-products' formation is promoted as soon as the specific input energy (SIE) increases. Between 70 and $350 \mathrm{~J} \cdot \mathrm{L}^{-1}$, there is a significant rise in each by-product concentration, $150 \%$ being the lowest increase observed. Between 350 and $1150 \mathrm{~J} \cdot \mathrm{L}^{-1}$, an almost constant production of $\mathrm{CO}_{2}$, methanol, acetone, methyl formate and nitromethane is observed; whereas an increase between $70 / 80 \%$ in CO, MeA, AcA and EdF, and of 108\% in EmF is still observed. Even if the amount of MN could not be quantified, the analyses of the DBD reactor effluent have shown that it is formed in higher quantities in the PDC process, and its production increases with SIE. Furthermore, introducing a catalyst in the discharge zone induces an increase in $\mathrm{CO}_{\mathrm{x}}$ selectivity. In fact, NTP at $150 \mathrm{~J} \cdot \mathrm{L}^{-1}$ has a $\mathrm{CO}_{\mathrm{x}}$ selectivity of $35 \%$ while in the PDC process this selectivity is equal to 36,50 and $60 \%$ for 70,350 and $1150 \mathrm{~J} \cdot \mathrm{L}^{-1}$, respectively. 


\subsection{Acetaldehyde Adsorption on $\mathrm{Ag} / \mathrm{TiO}_{2} / \mathrm{SiO}_{2}$}

In order to characterize the catalyst surface before turning the plasma on, in-situ DRIFTS was used to monitor the $\mathrm{Ag} / \mathrm{TiO}_{2} / \mathrm{SiO}_{2}$ surface during acetaldehyde adsorption. The adsorption capacity of the catalyst, at the experimental conditions used, was evaluated to be $698 \pm 3 \mu \mathrm{mol} / \mathrm{g}_{\text {catalyst }}$.

Figure 2 shows the infrared spectra of the silver-based catalyst surface after 1 and $30 \mathrm{~min}$ of exposition to $1000 \mathrm{ppmC}$ of $\mathrm{CH}_{3} \mathrm{CHO}$ at $298 \mathrm{~K}$ and atmospheric pressure. Acetaldehyde shows peaks in the $3000-2600 \mathrm{~cm}^{-1}$ region and $1800-1500 \mathrm{~cm}^{-1}$ region, as shown in the figure. After $1 \mathrm{~min}$ acetaldehyde adsorption, bands at 2936, 2922, 2866, 2770, 2748, 1759, 1713, 1555 and $1242 \mathrm{~cm}^{-1}$ are observed. Once the saturation is attained, after $30 \mathrm{~min}$, the previously mentioned absorption bands increase, and a new band appears at $2974 \mathrm{~cm}^{-1}$. In addition, broadband absorption features, associated with the peaks at 1713, 1555 and $1242 \mathrm{~cm}^{-1}$ are observed. The first broadband presents peaks at 1720 and $1713 \mathrm{~cm}^{-1}$; a small shoulder at $1697 \mathrm{~cm}^{-1}$, and a large shoulder in the $1690-1650 \mathrm{~cm}^{-1}$ range. The second broadband still showing a maximum at $1555 \mathrm{~cm}^{-1}$, and many smaller peaks in the $1590-1500 \mathrm{~cm}^{-1}$ range are visible after saturation of the surface with acetaldehyde. The last broadband also presents smaller peaks in the $1280-1210 \mathrm{~cm}^{-1}$ range.

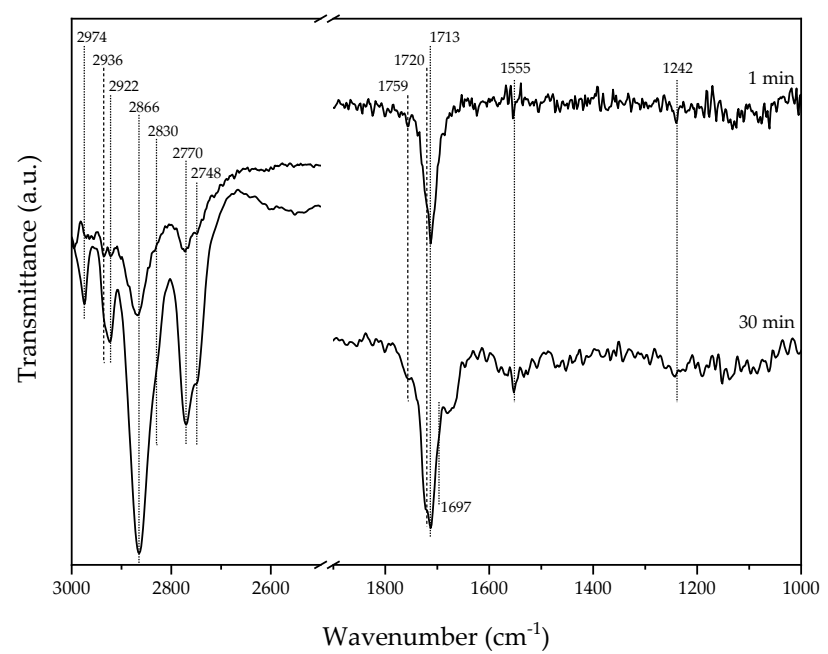

Figure 2. Diffuse-reflectance infrared Fourier transform spectroscopy (DRIFTS) spectra recorded after 1 and 30 min of acetaldehyde adsorption on $\mathrm{Ag} / \mathrm{TiO}_{2} / \mathrm{SiO}_{2}$ at $298 \mathrm{~K}$ and atmospheric pressure.

Peak assignments are presented in Table 2. In both spectra, bands in the $3000-2800 \mathrm{~cm}^{-1}$ region, the $\mathrm{CH}$ stretching region, can be assigned to symmetric and asymmetric $v\left(\mathrm{CH}_{3}\right)$ and $v\left(\mathrm{CH}_{2}\right)$ modes [30] and bands in the $1700-1680 \mathrm{~cm}^{-1}$ region can be assigned to $v(C=O)$ mode [31].

Table 2. Adsorbed acetaldehyde: observed bands and their assignments.

\begin{tabular}{cccc}
\hline \multirow{2}{*}{ Vibrational Mode } & \multicolumn{2}{c}{ Vibrational Assignments (cm ${ }^{-\mathbf{1}} \mathbf{~}$} & \multirow{2}{*}{ Reference } \\
\cline { 2 - 3 } & Gas Phase $\mathbf{C H}_{\mathbf{3}} \mathbf{C H O}$ & $\mathbf{C H}_{\mathbf{3}} \mathbf{C H O}$ Adsorbed on $\mathbf{A g} / \mathbf{T i O}_{\mathbf{2}} / \mathbf{S i O}_{\mathbf{2}}$ & \\
\hline$v_{\mathrm{as}}\left(\mathrm{CH}_{3}\right)$ & 2967 & 2974 & {$[30]$} \\
$v_{\mathrm{as}}\left(\mathrm{CH}_{2}\right)$ & & 2936 & {$[30-32]$} \\
$v_{\mathrm{s}}\left(\mathrm{CH}_{3}\right)$ & 2923 & 2922 & {$[30,33]$} \\
$2 v_{6} \mathrm{~A}^{\prime}$ Fermi & 2840 & 2866 & {$[34]$} \\
$v_{\mathrm{s}}\left(\mathrm{CH}_{2}\right)$ & & 2830 & {$[30]$} \\
$v(\mathrm{CH}) \eta^{1}$-acetaldehyde & 2736,2704 & 2770,2748 & {$[31,33,35]$} \\
$v(\mathrm{C}=\mathrm{O})$ & 1735 & 1713 & {$[31]$} \\
$v_{\text {as }}(\mathrm{COO})$ & & 1555 & {$[36]$} \\
\hline
\end{tabular}

From the literature, most of the bands in the $\mathrm{CH}$ stretching region could be assigned to adsorbed acetaldehyde [32-34]. However significant overlap of much of this region exists between acetaldehyde 
and the products of its heterogeneous reactions on oxide surfaces. Indeed, the bands at 2922, 2830 and $2748 \mathrm{~cm}^{-1}$ could be assigned to crotonaldehyde [33] whereas the band at $2936 \mathrm{~cm}^{-1}$ may also be assigned to other condensation products derived from surface reactions [31], or to acetate species [32]. The formation of crotonaldehyde is supported by the presence of the peak at $1720 \mathrm{~cm}^{-1}$ and the broad shoulder at $1690-1650 \mathrm{~cm}^{-1}[31,33,37-39]$ and the formation of acetate species is in agreement with the emergence of the broadband centered at $1555 \mathrm{~cm}^{-1}$ [36]. The dominant spectral feature in the $v(C=O)$ region, at $1713 \mathrm{~cm}^{-1}$, which is assigned to adsorbed acetaldehyde, shifts to lower wavenumbers with respect to the same band of $\mathrm{CH}_{3} \mathrm{CHO}$ in the gas phase. This indicates that acetaldehyde is bound to the surface $\mathrm{TiO}_{2}$ through its carbonyl group by $\mathrm{H}$-bridge bonding $[37,38,40]$. In addition, the growth of other infrared spectral features in this region points out the probable formation of other products such as acetone $\left(1697 \mathrm{~cm}^{-1}\right.$ [41]) or formaldehyde. Indeed, the band at $1242 \mathrm{~cm}^{-1}$ can be assigned to molecularly adsorbed formaldehyde [42,43], which has also been reported to present bands at 2913, $2863,2759,1648$ and $1413 \mathrm{~cm}^{-1}$ [42,44], supporting the presence of formaldehyde on the silver-based catalyst surface after acetaldehyde adsorption.

Although at the end of the adsorption step the $\mathrm{Ag} / \mathrm{TiO}_{2} / \mathrm{SiO}_{2}$ catalyst surface is mainly covered with adsorbed acetaldehyde, the other species which are also present have to be considered in order to better understand the acetaldehyde degradation mechanism in the following step of the process.

\subsection{Surface Species Formed during the PDC Process}

Once saturated with acetaldehyde, the $\mathrm{Ag} / \mathrm{TiO} \mathrm{S}_{2} / \mathrm{SiO}_{2}$ catalyst is used in order to decompose the VOC with the PDC process. Three different energies were used-70, 350 and $1150 \mathrm{~J} \cdot \mathrm{L}^{-1}$. Figure 3 shows the surface spectra of the catalyst before and after being exposed to the DBD discharge for $30 \mathrm{~min}$. It is clear that the surface species present on the surface after the adsorption process take part in different surface reactions while the plasma is on, leading to the modification of the surface composition as can be seen from the FTIR band features.

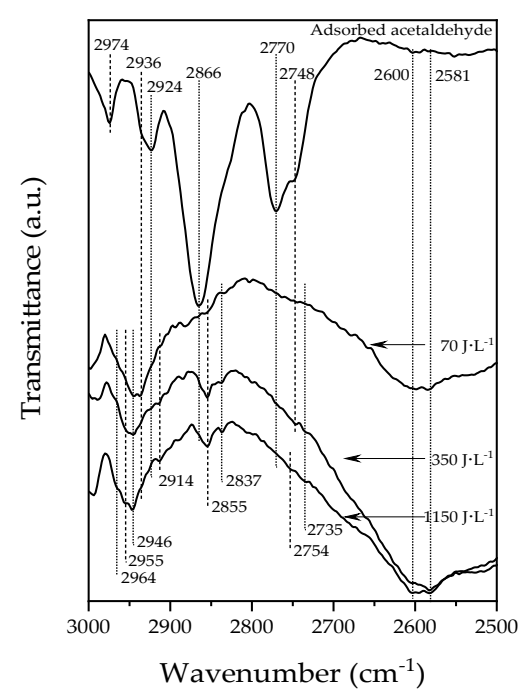

(a)

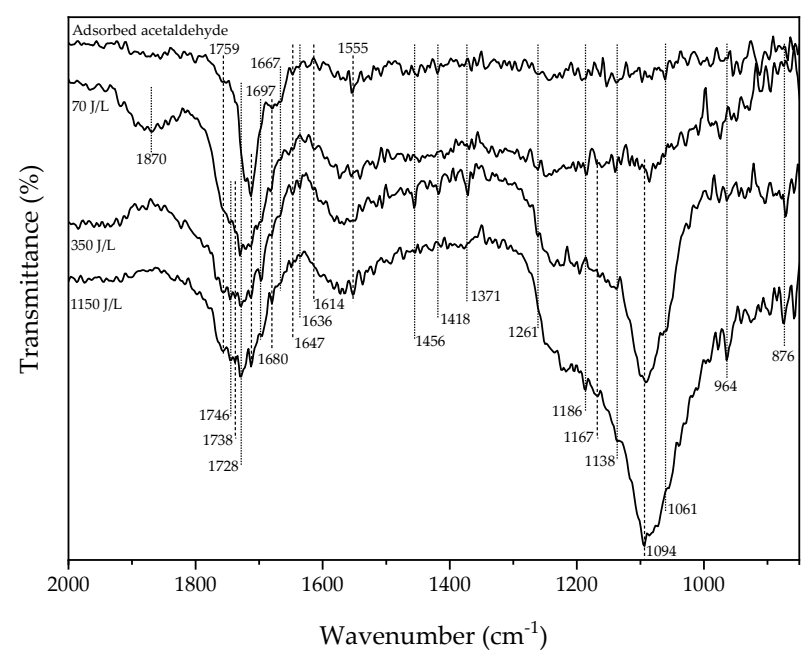

(b)

Figure 3. $\mathrm{Ag} / \mathrm{TiO}_{2} / \mathrm{SiO}_{2}$ catalyst surface DRIFTS spectra after saturation with $\mathrm{CH}_{3} \mathrm{CHO}$; and NTP effect on surface species at different plasma discharge energies: (a) $\mathrm{C}-\mathrm{H}$ stretching region; (b) bending region.

From Figure 3a it is clear that, after the PDC process, some of the bands disappear (2974 and $\left.2770 \mathrm{~cm}^{-1}\right)$ or almost disappear $\left(2748 \mathrm{~cm}^{-1}\right)$. The relative intensity of the bands in the $2970-2900 \mathrm{~cm}^{-1}$ region has clearly changed, with visible peaks at 2946, 2955 and $2964 \mathrm{~cm}^{-1}$; the band in the $2900-2800 \mathrm{~cm}^{-1}$ region decreases significantly; and a new broad band with peaks at 2600 and $2581 \mathrm{~cm}^{-1}$ appears. Figure $3 \mathrm{~b}$ shows an evident broadening of the bands centered at 1713, 1555 and 
$1242 \mathrm{~cm}^{-1}$ in the acetaldehyde-saturated surface. As the plasma input energy increases, the maximum of the $v(C=O)$ band is redshifted and its intensity decreases for an SIE higher than $70 \mathrm{~J} \cdot \mathrm{L}^{-1}$. At the same time, a band with increasing intensity develops in the $1300-1000 \mathrm{~cm}^{-1}$ region.

The loss of the bands at 2974 and $2770 \mathrm{~cm}^{-1}$ (assigned to adsorbed acetaldehyde), along with an intensity decrease of the peaks at 2866 and $1713 \mathrm{~cm}^{-1}$ indicates a gradual depletion of acetaldehyde surface species once the catalyst is in contact with the plasma. Likewise, the loss in intensity of the bands at 2922, 2830, 2748 and $1720 \mathrm{~cm}^{-1}$ indicates that less crotonaldehyde is present on the surface. Under the plasma effect, the $2950-2900 \mathrm{~cm}^{-1}$ band broadens, and presents different small peaks and shoulders with maximum intensities at 2946 and $2936 \mathrm{~cm}^{-1}$. The former peak may be assigned to surface methoxy [45]; indeed, along with the peak at $2946 \mathrm{~cm}^{-1}$, the presence of a small shoulder at $2924 \mathrm{~cm}^{-1}$ and a peak at $2855 \mathrm{~cm}^{-1}$ supports the possibility of the formation of surface methoxy [45-47]. Concerning the peak at $2936 \mathrm{~cm}^{-1}$, its attribution is less straightforward as it can be related to different surface species such as formate, ethoxy or acetate species $[32,44,45]$. On the one hand, the infrared features at 2964, 2955, 2936, 2924, 2866 and $2735 \mathrm{~cm}^{-1}$ bring out the formation of surface formate [45,48]. On the other hand, the peaks at 2964,2936, 2866 and $2855 \mathrm{~cm}^{-1}$ have also been assigned to ethoxy species formed on a $\mathrm{TiO}_{2}$ surface [37,44,49]. Furthermore, the peaks at 2964 and $2936 \mathrm{~cm}^{-1}$ have also been assigned to methyl acetate [35], whereas the one at $2936 \mathrm{~cm}^{-1}$ is also assigned to acetic acid [50]. The broad band between 2650 and $2550 \mathrm{~cm}^{-1}$ that appears after the plasma catalysis process supports the formation of formate species as it has been attributed to formic acid [51]. As the energy increases up to $350 \mathrm{~J} / \mathrm{L}$, the $2900-2800 \mathrm{~cm}^{-1}$ band loses intensity, the loss being more pronounced for the peak at $2936 \mathrm{~cm}^{-1}$; whereas the peaks at 2964 and $2955 \mathrm{~cm}^{-1}$, as well as a new peak at $2914 \mathrm{~cm}^{-1}$ become more visible. This latter peak may be attributed either to acetaldehyde [36], or to an intermediate formed from formaldehyde oxidation or disproportionation to give formate or methoxide, respectively $[52,53]$.

These attributions can be backed by the infrared features in the $2000-950 \mathrm{~cm}^{-1}$ region. Significant overlapping of the peaks in this wavelength range complicates precise identification of surface species but, based on litterature data, the bands generated on the plasma-exposed surface can be related to distinct vibrational modes of acetate, formate, methoxy, ethoxy, carbonate and formaldehyde species adsorbed on the surface of the $\mathrm{Ag} / \mathrm{TiO}_{2} / \mathrm{SiO}_{2}$ catalyst. Thus, we may assign some of the bands as presented in Table 3.

Table 3. Infrared (IR) bands assignment of the major surface species formed during the PDC process, in the $2000-950 \mathrm{~cm}^{-1}$ region.

\begin{tabular}{lll}
\hline \multicolumn{1}{c}{ Surface Species } & \multicolumn{1}{c}{ IR Band $\mathbf{( c m}^{-\mathbf{1}} \mathbf{c}$} & \multicolumn{1}{c}{ Reference } \\
\hline Acetate & $1560-1540 / 1450-1418$ & {$[33,39,46,54-56]$} \\
Formate & $1870-1828 / 1590-1550 / 1380-1350$ & {$[42,44,45,47,54,55,57-60]$} \\
Methoxy & $964 / 1100-1030$ & {$[61,62]$} \\
Ethoxy & $1456 / 1380-1390 / 1190-1090 / 1065-1050$ & {$[37,49,56,63]$} \\
Carbonate & $1680 / 1614 / 1520 / 1430 / 1310$ & {$[42]$} \\
Acetic acid & $1736 / 1675 / 1535 / 1453 / 1415 / 1341 / 1296 / 1025-1050$ & {$[44,46,56]$} \\
Formaldehyde & $1767-1746 / 1727-1713 / 1418 / 1260$ & {$[42,43,52,55]$} \\
\hline
\end{tabular}

The change in the vibrational spectrum of the catalyst surface following its exposure to NTP suggests a modification of its composition, which is directly related to the acetaldehyde decomposition mechanism.

\section{Discussion}

In this section we will propose a reaction pathway that takes into account acetaldehyde adsorption and its degradation on the surface with the PDC process. On the basis of the DBD reactor effluent analysis, and the infrared spectroscopic measurements carried out on the catalyst surface, it is evident that acetaldehyde undergoes a rather complex chemistry during the process. For this reason, a detailed 
description of the acetaldehyde decomposition mechanism is out-of-reach at this point. Alternatively, we propose a series of simplified adsorption/degradation routes in order to account for the key aspects of surface activity that lead to the formation of the different identified surface species, and a subsequent increase in acetaldehyde degradation, which results in an increase in the amount of gaseous by-products.

\subsection{Acetaldehyde Adsorption Mechanism}

In different studies concerning the photocatalytic degradation pathway of acetaldehyde on a $\mathrm{TiO}_{2}$ surface, it has been noticed that, upon adsorption of acetaldehyde, different species are already formed without illuminating the catalyst. Two compounds, 3-hydroxybutanal and crotonaldehyde, are formed through an aldol condensation, while bidentate acetate species have been detected to be formed by an oxidation process occurring on the $\mathrm{TiO}_{2}$ surface [40].

As suggested from the spectra analysis of the saturated surface, when acetaldehyde is brought into contact with the nanostructured $\mathrm{TiO}_{2}$, it will certainly bind to the surface through the oxygen atom of its carbonyl group. Then, two acetaldehyde molecules adsorbed on neighboring sites can react through a $\beta$-aldolization reaction to give crotonaldehyde, $\mathrm{CH}_{3}(\mathrm{CH})_{2} \mathrm{CHO}[28,31,33,64-66]$. It has been shown that acetaldehyde undergoes aldol condensation forming 3-hydroxybutanal $\left(\mathrm{CH}_{3} \mathrm{CH}(\mathrm{OH}) \mathrm{CH}_{2} \mathrm{CHO}\right)$ which, upon dehydration forms crotonaldehyde [31,34,40]:

$$
\mathrm{CH}_{3} \mathrm{CHO}_{\mathrm{ads}}+\mathrm{CH}_{3} \mathrm{CHO}_{\text {ads }} \rightarrow \mathrm{CH}_{3}-\mathrm{CH}=\mathrm{CH}-\mathrm{CHO}_{\mathrm{ads}}+\mathrm{H}_{2} \mathrm{O}
$$

Formation of acetate species can result from the direct oxidation on the surface of acetaldehyde [30, $32,46,66]$, and to a lesser extent of crotonaldehyde [40], through a surface oxygen $\left(\mathrm{O}_{\mathrm{s}}\right)$ :

$$
\mathrm{CH}_{3} \mathrm{CHO}_{\mathrm{ads}}+\mathrm{O}_{\mathrm{s}} \rightarrow \mathrm{CH}_{3} \mathrm{COO}_{\text {ads }}^{-}+\mathrm{H}_{\text {ads }}^{+}
$$

Besides, a Cannizzaro disproportionation of two acetaldehyde molecules involving a vacancy $\left(\mathrm{V}_{\mathrm{O}}\right)$ and surface oxygen would result in the formation of acetate and ethoxy groups. This pathway has been proposed for acetaldehyde adsorption on rutile $\mathrm{TiO}_{2}$ [33]:

$$
2 \mathrm{CH}_{3} \mathrm{CHO}_{\mathrm{ads}}+\mathrm{V}_{\mathrm{O}} / \mathrm{O}_{\mathrm{s}} \rightarrow \mathrm{CH}_{3} \mathrm{COO}_{\text {ads }}^{-}+\mathrm{CH}_{3} \mathrm{CH}_{2} \mathrm{O}_{\text {ads }}^{-}
$$

Despite the fact that it is difficult to ascertain the presence of ethoxy species from the spectra in Figure 2, their presence at much smaller levels than acetates cannot be completely ruled out.

Concerning acetone formation on oxide surfaces from aldehydes, two pathways are mainly known. The first is via a two-step reaction: oxidation to carboxylates followed by the coupling of two carboxylates to form one molecule of ketone. The second pathway is through the reaction of an adsorbed acyl group, $\mathrm{RC}=\mathrm{O}$, with an alkyl group [32]. Examples of acetone formation from acetaldehyde via these two pathways have been reported, but they concern studies carried out at temperatures well above the ambient temperature [32,67-69]. Another possibility is acetone formation through 3-hydroxybutanal. Indeed, at ambient temperature this compound is very reactive and, either it undergoes fast dehydration on the surface to form crotonaldehyde; or it can be converted via intramolecular $\mathrm{H}$ transfer to 4-hydroxybutan-2-al $\left(\mathrm{CH}_{3} \mathrm{C}(\mathrm{O}) \mathrm{CH}_{2} \mathrm{CH}_{2} \mathrm{OH}\right)$. The latter can be further transferred into acetone $\left(\mathrm{CH}_{3} \mathrm{C}(\mathrm{O}) \mathrm{CH}_{3}\right)$ and formaldehyde $(\mathrm{HC}(\mathrm{O}) \mathrm{H})$ via reverse reaction to aldol condensation [34]:

$$
2 \mathrm{CH}_{3} \mathrm{CHO}_{\text {ads }} \rightarrow \mathrm{CH}_{3} \mathrm{CH}(\mathrm{OH}) \mathrm{CH}_{2} \mathrm{CHO}_{\text {ads }} \leftrightarrow \mathrm{CH}_{3} \mathrm{C}(\mathrm{O}) \mathrm{CH}_{2} \mathrm{CH}_{2} \mathrm{OH} \rightarrow \mathrm{HC}(\mathrm{O}) \mathrm{H}+\mathrm{CH}_{3} \mathrm{C}(\mathrm{O}) \mathrm{CH}_{3}
$$

This mechanism is a very plausible one, as it explains acetone and formaldehyde formation after acetaldehyde adsorption at ambient temperature. 


\subsection{Surface Species Formed during the PDC Process: Formation Mechanism}

Before turning the plasma on, the catalyst surface is mainly composed of adsorbed acetaldehyde. Part of this acetaldehyde yields crotonaldehyde (Reaction (1)); acetate (Reactions (2) and (3)), acetone and formaldehyde (Reaction (4)). DRIFTS measurements carried out on the catalyst exposed to the plasma reveal that acetaldehyde degradation proceeds with the formation of different surface compounds such as acetate, methoxy, ethoxy, formate and carbonate species, as well as formaldehyde and formic and acetic acid. It should be noted that, despite being referred to as formic acid and acetic acid, it is most likely formate and acetate species on the surface [40]. Indeed, previous studies have shown that photocatalytic oxidation of acetaldehyde could yield acetic and formic acid that remain adsorbed on the surface in a dissociated form, i.e., as acetate and formate, respectively (degradation routes Reactions (5) and (6)) [55,69].

$$
\begin{gathered}
\mathrm{CH}_{3} \mathrm{CHO}_{\mathrm{a}} \rightarrow \mathrm{CH}_{3} \mathrm{COO}_{\mathrm{a}}^{-}+\mathrm{H}_{\mathrm{a}}^{+} \\
\mathrm{CH}_{3} \mathrm{CHO}_{\mathrm{a}} \rightarrow \mathrm{HCHO}_{\mathrm{a}} \rightarrow \mathrm{HCOO}_{\mathrm{a}}^{-}+\mathrm{H}_{\mathrm{a}}^{+}
\end{gathered}
$$

The formation of acetate species on the catalyst surface has already been presented in the previous section. Nevertheless, once the plasma is turned on, two more routes may be considered. One route involves the acetyl radical resulting from adsorbed acetaldehyde decomposition by the plasma; which in turn can react with gas-phase oxygen to form acetate species (Reaction (7)) [56]. The other one is the reaction of gaseous acetaldehyde with an activated surface oxygen (Reaction (8)) [70]—indeed, it has been shown that the presence of silver atoms enhances the adsorption of oxygen on the catalyst and promotes its activation $[22,71] \cdot \frac{\text { above above above }}{\text { below below below }}$

$$
\begin{gathered}
\mathrm{CH}_{3} \mathrm{CHO}_{\mathrm{a}} \rightarrow \mathrm{CH}_{3} \mathrm{CO}_{\mathrm{a}}+\mathrm{H}_{\mathrm{a}} \stackrel{+\mathrm{O}_{2}}{\longrightarrow} \mathrm{CH}_{3} \mathrm{COO}_{\mathrm{a}}^{-} \\
\mathrm{CH}_{3} \mathrm{OH}_{\mathrm{g}}+\mathrm{O}_{\mathrm{a}} \rightarrow \mathrm{CH}_{3} \mathrm{COO}_{\mathrm{a}}^{-}+\mathrm{H}_{\mathrm{a}}^{+}
\end{gathered}
$$

Regarding formate species, its formation through oxidation of different compounds such as acetone (Reaction (9)) [55], acetate species (Reactions (10) and (11)) [46,55], formaldehyde (Reaction (12)) [55,72-74] and crotonaldehyde (Reaction (13)) [64] should be considered.

$$
\begin{aligned}
\mathrm{CH}_{3} \mathrm{C}(\mathrm{O}) \mathrm{CH}_{3} \mathrm{a} & \stackrel{\mathrm{O}_{2}}{\longrightarrow} 2 \mathrm{HCOO}_{\mathrm{a}}^{-}+\mathrm{H}_{\mathrm{a}}^{+}+\mathrm{CO}_{2} \\
\mathrm{CH}_{3} \mathrm{COO}_{\mathrm{a}}^{-}+\mathrm{H}^{+} & \rightarrow \mathrm{HCOO}_{\mathrm{a}}^{-}+\mathrm{H}_{\mathrm{a}}^{+} \\
\mathrm{CH}_{3} \mathrm{COO}_{\mathrm{a}}^{-} \rightarrow \mathrm{CH}_{3} \mathrm{O}_{\mathrm{a}} & \rightarrow \mathrm{CH}_{2} \mathrm{O}_{\mathrm{a}} \rightarrow \mathrm{HCOO}_{\mathrm{a}}^{-} \\
\mathrm{HCHO}+\mathrm{O}_{\mathrm{a}} & \rightarrow \mathrm{HCOO}_{\mathrm{a}}^{-} \\
\mathrm{CH}_{3}(\mathrm{CH})_{2} \mathrm{CHO}_{\mathrm{a}} & \rightarrow \mathrm{HCOO}_{\mathrm{a}}^{-}+\mathrm{H}_{\mathrm{a}}^{+}
\end{aligned}
$$

Methoxy species may be formed following different routes, one of which involves methanol, a by-product of acetaldehyde decomposition by NTP. The proposed routes are direct oxidation of surface acetate species (Reaction (14)) [46], and dissociative adsorption of methanol (Reaction (15)) [75,76]. Indeed, on the basis of reaction mechanisms derived from model studies carried out under ultrahigh vacuum conditions on noble metal surfaces, methanol is activated by surface oxygen so that adsorbed methoxy species can form [77].

$$
\begin{gathered}
\mathrm{CH}_{3} \mathrm{COO}_{\mathrm{a}}^{-} \rightarrow \mathrm{CH}_{3} \mathrm{O}_{\mathrm{a}}+\mathrm{CO}_{2}(\mathrm{~g}) \\
\mathrm{CH}_{3} \mathrm{OH}_{\mathrm{g}}+\mathrm{S} \rightarrow \mathrm{CH}_{3} \mathrm{O}_{\mathrm{a}}+\mathrm{H}_{\mathrm{a}}^{+}
\end{gathered}
$$

where $\mathrm{S}$ is a site on the oxide surface. 
Concerning ethoxy species, one possible pathway has already been proposed through the Reaction (3) route. Moreover, it has been shown that $\mathrm{TiO}_{2}$-supported catalysts may significantly promote the reaction of acetaldehyde with adsorbed hydrogen formed in previous steps to form ethoxy species [54,66] (Reaction (16)).

$$
\mathrm{CH}_{3} \mathrm{CHO}_{\mathrm{a}}+\mathrm{H}_{\mathrm{a}}^{+} \rightarrow \mathrm{CH}_{3} \mathrm{CH}_{2} \mathrm{O}_{\mathrm{a}}^{-}
$$

As for carbonate species, they may be produced from acetates (Reactions (17) and (18)) $[56,67,70]$. Furthermore, an investigation carried out using supported $\mathrm{TiO}_{2}$ catalysts in the presence of $\mathrm{H}_{2} \mathrm{O}_{2}$ [58] has shown that formate species interaction with the surface can lead to carbonate and acetone formation (Reaction (19)). This latter possibility should be considered in our case, as NTP is able to generate $\mathrm{H}_{2} \mathrm{O}_{2}$.

$$
\begin{gathered}
\mathrm{CH}_{3} \mathrm{COO}_{\mathrm{a}}^{-}+\mathrm{OH}_{\mathrm{s}} \rightarrow \mathrm{CO}_{3 \mathrm{a}}^{2-}+\mathrm{CH}_{4} \\
2 \mathrm{CH}_{3} \mathrm{COO}_{\mathrm{a}}^{-} \rightarrow \mathrm{CH}_{3} \mathrm{C}(\mathrm{O}) \mathrm{CH}_{3} \mathrm{a}+\mathrm{CO}_{3}^{2-} \mathrm{a} \\
\mathrm{HCOO}_{\mathrm{a}}^{-} \stackrel{\mathrm{H}_{2} \mathrm{O}_{2}}{\longrightarrow} \mathrm{CO}_{3}^{2-} \mathrm{a}
\end{gathered}
$$

Regarding formaldehyde formation, in addition to Reaction (4) route, other routes may also be allowed for. These include formation of formaldehyde from acetaldehyde on $\mathrm{TiO}_{2}$ surfaces, either directly or through an acetate intermediary (Reaction (20)) [55], from acetaldehyde oxidation by surface oxygen (Reaction (21)) [54], from surface ethoxy and methoxy species oxidation (Reactions (22) and (23)) $[44,46,57]$ and as an intermediate in methanol oxidation (Reaction (24)) [74].

$$
\begin{gathered}
\mathrm{CH}_{3} \mathrm{CHO}_{\mathrm{a}} \stackrel{\left(\mathrm{CH}_{3} \mathrm{COO}_{\mathrm{a}}^{-}\right)}{\longrightarrow} \mathrm{HCHO}_{\mathrm{a}}+\mathrm{HCOOH}_{\mathrm{a}} \\
\mathrm{CH}_{3} \mathrm{CHO}_{\mathrm{a}}+2 \mathrm{O}_{\mathrm{s}} \rightarrow \mathrm{HCHO}_{\mathrm{a}}+\mathrm{HCOOH}_{\mathrm{a}} \\
\mathrm{CH}_{3} \mathrm{CH}_{2} \mathrm{O}_{\mathrm{a}}^{-} \rightarrow \mathrm{HCHO}_{\mathrm{a}} \\
\mathrm{CH}_{3} \mathrm{O}_{\mathrm{a}} \rightarrow \mathrm{HCHO}_{\mathrm{a}}+\frac{1}{2} \mathrm{H}_{2} \mathrm{~g} \\
\mathrm{CH}_{3} \mathrm{OH} \rightarrow \mathrm{HCHO}_{\mathrm{a}}+\mathrm{H}_{2} \text { ads }
\end{gathered}
$$

It can be seen that routes through Reactions (20) and (21) are not only a possible source of formaldehyde, but also of formic acid.

Some authors working with photocatalytic degradation of acetaldehyde have also observed that the initially formed species, 3-hydroxybutanal and crotonaldehyde, are converted to other intermediates upon illumination of the catalyst. Among the main intermediates, they have identified formic acid, acetic acid and formaldehyde, and this is in accordance with our results [40,64].

It is important to bear in mind that some of the species identified on the catalyst surface after the PDC process can also be formed directly in the gas phase. Indeed, gas-phase acetaldehyde decomposition by NTP can lead to the formation of methoxy radical, as well as acetone, acetic acid and formaldehyde [78], which can subsequently adsorb on the surface.

\subsection{Proposed Simplified Mechanism for Acetaldehyde Decomposition Using the Plasma/Catalysis Process}

From the identified gaseous by-products, surface IRbands' assignment and proposed adsorption/ degradation routes-a schematic diagram of the possible pathways for acetaldehyde degradation over $\mathrm{Ag} / \mathrm{TiO}_{2} / \mathrm{SiO}_{2}$ in the PDC process is presented in Figure 4. It is worth noting that we have not detected formaldehyde at the exit of the DBD reactor whereas it has been detected on the catalyst surface. There are two reasons for this: formaldehyde is a short-lived species [77] and it is strongly adsorbed onto silver catalyst [79]. 


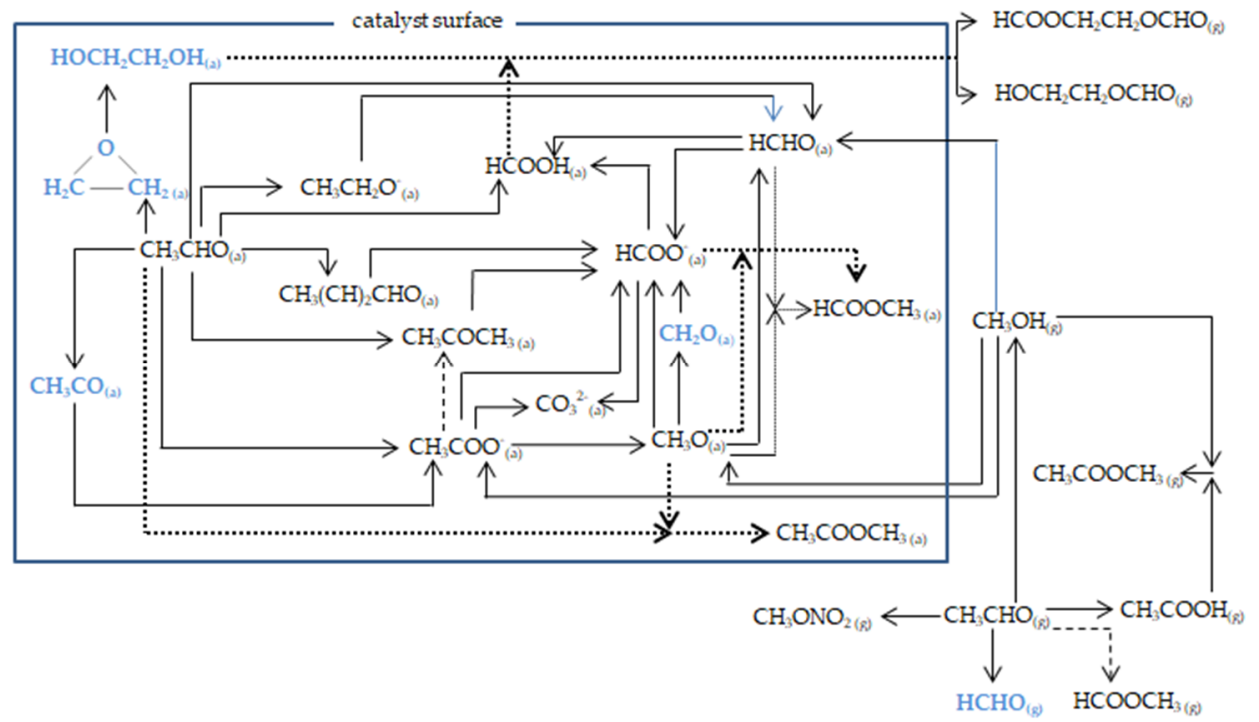

Figure 4. Schematic diagram of the proposed reaction pathway of the PDC degradation of acetaldehyde on $\mathrm{Ag} / \mathrm{TiO}_{2} / \mathrm{SiO}_{2}$. The line patterns (solid line, dotted line, dashed line) represent, respectively, either direct routes or routes involving reactions with simple radicals/atoms/sites on the surface $\left(\mathrm{H} / \mathrm{OH} / \mathrm{O} / \mathrm{V}_{\mathrm{O}} / \mathrm{S}\right)$, routes involving two surface species and routes leading to the formation of by-products observed only at high energy. Blue color compounds: not detected/identified.

It is very likely that $\mathrm{EdF}$ and $\mathrm{EmF}$ are formed through the esterification of ethylene glycol (EG) and formic acid, even if there is no evidence of the presence of EG either on the effluent or on the surface. However, it is well-known that silver catalysts are commonly used in the manufacturing process for the direct oxidation of ethylene to ethylene oxide (EO) [80], and EO is a precursor of EG [81,82]. Besides, ethylene and EO can be formed from acetaldehyde decomposition on the surface [83-86]. Thus, $\mathrm{EdF}$ and EmF formation through an EG pathway is very plausible in the PDC process. In addition, low-energy, electron-induced processes on Me have been proven to induce the formation of methoxy $\left(\mathrm{CH}_{3} \mathrm{O}\right)$ and hydroxymethyl $\left(\mathrm{CH}_{2} \mathrm{OH}\right)$ radicals via electron impact excitation, which, followed by radical-radical coupling, can lead to EG and formic acid formation [87], therefore explaining EmF and EdF production with NTP alone.

In this diagram we did not include the pathways leading to $\mathrm{CO}_{2}$ and $\mathrm{CO}$ formation as there are many possibilities. The different routes to $\mathrm{CO}_{x}$ can involve many of the different adsorbed species or gaseous organic compounds. Nevertheless, it is worth noting that increasing the energy in the PDC process also increases the selectivity towards CO. In order to explain this result, we have proposed in a previous work a decarbonylation process of acetaldehyde on the silver-based catalyst [27]. However, this higher $\mathrm{CO}$ selectivity can also be the result of the by-products' decomposition pathways. According to a study on the mechanism of the heterogeneously-catalyzed oxidation of organic molecules on metal oxides, it has been stated that formate ions rather easily decompose to CO over metal oxides [88]. Furthermore, an experimental study of ozone catalytic oxidation of gaseous formaldehyde using a $\mathrm{TiO}_{2}$-supported catalyst at room temperature has shown that $\mathrm{CO}_{\mathrm{x}}$ selectivity is dependent on the $\mathrm{O}_{3}: \mathrm{HCHO}$ ratio and the relative humidity (RH). In this work, for a $\mathrm{O}_{3}: \mathrm{HCHO}$ ratio of 5 (best ratio) and $20 \% \mathrm{RH}, 90 \%$ of $\mathrm{HCHO}$ removal and a $\mathrm{CO} / \mathrm{CO}_{2}$ ratio of 1.5 were achieved, making $\mathrm{CO}$ the major product [89]. Similar results regarding higher conversion towards $\mathrm{CO}$ than $\mathrm{CO}_{2}$ where obtained when using $\mathrm{TiO}_{2}$-supported catalysts for ethanol oxidation; and it is well-known that acetaldehyde is one of the major intermediate species in ethanol decomposition [70].

As presented in Section 2.1, except from Ace and the fraction corresponding to the unknown compounds, the same by-products are obtained with the NTP and PDC processes. This fact allows the drawing of an initial conclusion concerning Ace and MeF formation. Indeed, at the experimental conditions used, Ace seems to be generated only on the surface, and most certainly through the 
ketonization of acetic acid/acetate species. In addition, with NTP at $150 \mathrm{~J} \cdot \mathrm{L}^{-1}$ there is no formation of MeF, whereas with the PDC process it is already formed at $70 \mathrm{~J} \cdot \mathrm{L}^{-1}$, and in equivalent amounts to the other acetate/formate compounds. Thus, it is clear that the catalyst surface promotes MeF formation. As mentioned earlier, Me can be activated by surface oxygen. In a study on methanol oxidation over silver catalysts, the authors reported that the catalytic oxidative reaction of methanol to methyl formate is related to a synergic process concerning oxygen species on the silver surface. The mechanism proposed in this $\mathrm{O}_{\mathrm{s}}$-Me system starts with methanol dehydrogenation to form adsorbed formaldehyde and methoxy; thereafter, formaldehyde reacts with adsorbed $\mathrm{OH}$ or $\mathrm{O}$ to form adsorbed formate, that reacts with methoxy and forms methyl formate $[79,90]$. Thus, Me formed as a by-product of acetaldehyde decomposition can be the precursor of $\mathrm{MeF}$, with formaldehyde and $\mathrm{CH}_{3} \mathrm{O}$ as intermediates. In addition, as presented in Figure $1, \mathrm{NTP}$ at $150 \mathrm{~J} \cdot \mathrm{L}^{-1}$ produces more Me and AcA than the PDC process. Thus, we can suggest that the lower amount of Me is related to its decomposition into formaldehyde and $\mathrm{CH}_{3} \mathrm{O}$, that will in turn produce $\mathrm{MeF}$; and the lower amount of AcA is probably related to the preferential decomposition of acetate through other routes than the one at its origin. From spectra in Figure 3 we have seen that bands corresponding to methoxy, acetate and formaldehyde are present at $70 \mathrm{~J} \cdot \mathrm{L}^{-1}$, which stresses the feasibility of the proposed mechanisms for Ace and MeF formation.

Increasing SIE from 70 to $350 \mathrm{~J} \cdot \mathrm{L}^{-1}$ increases acetaldehyde degradation from $33 \%$ to $87 \%$, which leads to an important rise in the concentration of all the identified by-products. CO concentration increases 8-fold, whereas the other compounds experience a 2.5- to 4-fold increase. This result confirms the fact that acetaldehyde degradation follows a pathway favoring $\mathrm{CO}$ formation. Concerning the catalyst surface composition, in Figure $3 \mathrm{~b}$ we can see the emergence of a peak at $2914 \mathrm{~cm}^{-1}$, which has been assigned in Section 2.3 either to adsorbed acetaldehyde or to an intermediate formed from formaldehyde oxidation or disproportionation. Considering all the above, this peak could rather be assigned to the intermediate formed from formaldehyde oxidation to formate species, that will subsequently lead to the formation of the different formate compounds. This is supported by the loss of the band centered at $1870 \mathrm{~cm}^{-1}$, attributed to formate species, for which desorption from the surface may be favored at this energy. Similarly, the growth of a rather broad band in the $1300-950 \mathrm{~cm}^{-1}$ region observed in Figure 3a should rather be assigned to methoxy species that can also promote formate species formation.

When increasing SIE to $1150 \mathrm{~J} \cdot \mathrm{L}^{-1}$, two different behaviors among the by-products were observed: (i) those whose concentration remains rather constant $\left(\mathrm{CO}_{2}, \mathrm{MeO}, \mathrm{MeF}\right.$ and Ace), (ii) those whose concentration almost doubled (CO, MeA, EdF, EmF and AcA). Therefore, it seems that once formate/ formaldehyde are formed, the path that would be favored is the one towards formic acid and then EmF and EdF. Additionally, acetates will be transformed into AcA and MeA rather than into Ace.

\section{Materials and Methods}

\subsection{Catalyst Preparation}

Silver nanoparticles deposition was performed following the method presented in a previous study [91]. In this same study, atomic force microscopy (AFM, Veeco, Munich, Germany), scanning electron microscopy (SEM, Supra 40 VP, Zeiss, France) and transmission electron microscopy (TEM, 200 kV JEM 2011, JEOL, France) measurements showing a homogeneous dispersion of silver nanoclusters on the $\mathrm{TiO}_{2}$ monolayer can be found. The silver nanoparticles were deposited on $150-\mu \mathrm{m}$-diameter $\mathrm{SiO}_{2}$ pellets (Sigma-Aldrich silica gel, St. Louis, MO, USA). The pellets were first covered by a size-selected titanium oxo-alkoxy (TOA, Sigma-Aldrich, St. Louis, MO, USA, 99.999\% purity)) nanoparticles monolayer synthesized in a rapid micromixing sol-gel reactor. Then, the silver nanoclusters (10 nm mean diameter) were grown on the TOA monolayer by photocatalytic reduction of an $\mathrm{Ag}^{+}$aqueous solution $\left(\mathrm{AgNO}_{3}\right.$, Prolabo, Prolabo, Paris, France, 99.8\% purity), under ultraviolet (UV) irradiation (Philips, Haarlem, The Netherlands, operating at $362 \pm 10 \mathrm{~nm}, 8 \mathrm{~W})$. Finally, the pellets were washed in distilled water and 
dried at $80^{\circ} \mathrm{C}$ for $4 \mathrm{~h}$. A $303 \mathrm{~m}^{2} \mathrm{~g}^{-1}$ BET (Brunauer-Emmet-Teller) (Beckman Coulter, Brea, CA, USA, $\left.\mathrm{SA}^{\mathrm{TM}} 3100\right)$ specific surface area was measured.

\subsection{Plasma/Catalysis Process}

A DBD reactor previously described [27], was used for acetaldehyde removal at room temperature and atmospheric pressure. The DBD reactor is composed of a quartz cylinder externally covered by a grounded stainless steel. A sinusoidal high voltage is applied to a stainless steel cylindrical center electrode through a 5-mm gap. This high voltage is obtained using a voltage amplifier (TREK, 20/20 C, France), coupled to a frequency generator. Different values of the specific input energy (SIE in J. $\mathrm{L}^{-1}$ ), defined as the ratio of the discharge power $(W)$ over the flow rate $\left(\mathrm{L} \cdot \mathrm{s}^{-1}\right)$, were obtained by changing the frequency of the signal. When using the $\mathrm{PDC}$ process, the $\mathrm{Ag} / \mathrm{TiO} \mathrm{S}_{2} / \mathrm{SiO}_{2}$ nanostructured catalyst was placed in the plasma discharge zone.

The pollutant mixture was composed of acetaldehyde (1000 ppmC), oxygen $(20 \%)$ and nitrogen (balance) (Air Liquide Alphagaz ${ }^{\mathrm{TM}}$ ), and the flow rate was set to $100 \mathrm{~mL} \cdot \mathrm{min}^{-1}$ (Bronkhorst El-Flow ${ }^{\circledR}$ Select). The gas was admitted at the bottom of the DBD reactor and flowed upward through the fluidized bed. At the exit, it was sent to a set of analyzers: gas chromatography (Shimadzu GC-2110, Shimadzu, Noisiel, France), for quantitative analysis of residual acetaldehyde; gas chromatography coupled to mass spectrometry, for identification of the gaseous by-products (Shimadzu 2110-GC coupled to a QP2010S-MS, Shimadzu, Noisiel, France); and an infrared multigas analyzer (MIR 9000, Environment SA, France), for $\mathrm{CO}_{2}$ and $\mathrm{CO}$ quantification. The plasma-catalysis experiments were carried out in two stages: (i) the catalyst surface was saturated by acetaldehyde at room temperature and atmospheric pressure, and (ii) the plasma discharge was switched on for 30 min to induce acetaldehyde removal on the surface in the same temperature and pressure conditions. The surface was then characterized by DRIFTS analysis.

\subsection{DRIFTS Measurements}

DRIFTS analyses were performed with a Shimadzu IRPrestige-21 spectrophotometer (DLATGS detector, 100 scans accumulation, and $4 \mathrm{~cm}^{-1}$ resolution, Shimadzu, France). A Pike DiffusIRTM accessory (Pike, Eurolabo, France) containing a chamber equipped with a $\mathrm{KBr}$ window was adapted on the FTIR spectrophotometer. This chamber can contain a cup with approximately $10 \mathrm{mg}$ of catalyst. All DRIFTS spectra presented were acquired in transmittance mode.

\section{Conclusions}

In summary, we used DRIFT spectroscopy to identify the adsorbed species formed on an $\mathrm{Ag} / \mathrm{TiO}_{2} / \mathrm{SiO}_{2}$ surface during acetaldehyde adsorption and degradation with a PDC process. The measurements showed that different species such as acetate, formate, methoxy, ethoxy and formaldehyde are present on the surface, once it has been in contact with the plasma.

A pathway that considers the formation of these intermediates via the interaction of adsorbed acetaldehyde, and the plasma-generated species and/or by-products of acetaldehyde decomposition in the gas phase is proposed. The main carbonaceous intermediates identified allowed more detailed mechanism for acetaldehyde degradation to be given, as well as the formation of most of the identified by-products detected in the gas phase leaving the reactor to be explained.

Further investigations are needed to include nitrogenous species detected in the gas phase in the mechanism of acetaldehyde degradation with the PDC process. It is very likely that in $\mathrm{CH}_{3} \mathrm{CHO}$ degradation the presence of methanol, one of the intermediate by-products in $\mathrm{CH}_{3} \mathrm{CHO}$ oxidation, combined with oxygen activation by silver atoms on the surface, are key elements in the performance of the PDC process. 
Author Contributions: Conceptualization, A.V.-G., X.D. and S.S.; Formal analysis, A.V.-G., X.D. and S.S.; Funding acquisition, X.D.; Investigation, A.V.-G., X.D. and S.S.; Methodology, A.V.-G., X.D. and S.S.; Supervision, A.V.-G. and X.D.; Validation, A.V.-G. and X.D.; Writing-original draft, A.V.-G. All authors have read and agreed to the published version of the manuscript.

Funding: This research was funded by the ANR Programme Blanc grant ANR-08-BLAN-015-01 à 04)) and Region Ile de France grant IF-110005975 and 10005961).

Acknowledgments: The authors wish to thank Nicolas Fagnon for the Labview program used for the automated data acquisition during the DRIFTS experiments.

Conflicts of Interest: The authors declare no conflict of interest.

\section{References}

1. Li, K.; Ji, J.; Huang, H.; He, M. Efficient activation of $\mathrm{Pd} / \mathrm{CeO}_{2}$ catalyst by non-thermal plasma for complete oxidation of indoor formaldehyde at room temperature. Chemosphere 2020, 246, 125762. [CrossRef] [PubMed]

2. Lee, H.; Song, M.Y.; Ryu, S.; Park, Y.-K. Acetaldehyde oxidation under high humidity using a catalytic non-thermal plasma system over Mn-loaded Y zeolites. Mater. Lett. 2020, 262, 127051. [CrossRef]

3. Vandenbroucke, A.M.; Nguyen Dinh, M.T.; Nuns, N.; Giraudon, J.M.; De Geyter, N.; Leys, C.; Lamonier, J.F.; Morent, R. Combination of non-thermal plasma and $\mathrm{Pd} / \mathrm{LaMnO}_{3}$ for dilute trichloroethylene abatement. Chem. Eng. J. 2016, 283, 668-675. [CrossRef]

4. Magureanu, M.; Mandache, N.B.; Eloy, P.; Gaigneaux, E.M.; Parvulescu, V.I. Plasma-assisted catalysis for volatile organic compounds abatement. Appl. Catal. B Environ. 2005, 61, 12-20. [CrossRef]

5. Vandenbroucke, A.M.; Morent, R.; De Geyter, N.; Leys, C. Non-thermal plasmas for non-catalytic and catalytic VOC abatement. J. Hazard. Mater. 2011, 195, 30-54. [CrossRef]

6. Fan, X.; Zhu, T.L.; Wang, M.Y.; Li, X.M. Removal of low-concentration BTX in air using a combined plasma catalysis system. Chemosphere 2009, 75, 1301-1306. [CrossRef]

7. Feng, X.; Liu, H.; He, C.; Shen, Z.; Wang, T. Synergistic effects and mechanism of a non-thermal plasma catalysis system in volatile organic compound removal: A review. Catal. Sci. Technol. 2018, 8, 936-954. [CrossRef]

8. Wang, B.; Xu, X.; Xu, W.; Wang, N.; Xiao, H.; Sun, Y.; Huang, H.; Yu, L.; Fu, M.; Wu, J.; et al. The Mechanism of Non-thermal Plasma Catalysis on Volatile Organic Compounds Removal. Catal. Surv. Asia 2018, 22, 73-94. [CrossRef]

9. Schiavon, M.; Torretta, V.; Casazza, A.; Ragazzi, M. Non-thermal Plasma as an Innovative Option for the Abatement of Volatile Organic Compounds: A Review. Water Air Soil Pollut. 2017, 228, 388. [CrossRef]

10. Perillo, R.; Ferracin, E.; Giardina, A.; Marotta, E.; Paradisi, C. Efficiency, products and mechanisms of ethyl acetate oxidative degradation in air non-thermal plasma. J. Phys. D Appl. Phys. 2019, 52, 295206. [CrossRef]

11. Bal, K.M.; Huygh, S.; Bogaerts, A.; Neyts, E.C. Effect of plasma-induced surface charging on catalytic processes: Application to $\mathrm{CO}_{2}$ activation. Plasma Sources Sci. Technol. 2018, 27, 024001. [CrossRef]

12. Song, H.; Hu, F.; Peng, Y.; Li, K.; Bai, S.; Li, J. Non-thermal plasma catalysis for chlorobenzene removal over $\mathrm{CoMn} / \mathrm{TiO}_{2}$ and $\mathrm{CeMn} / \mathrm{TiO}_{2}$ : Synergistic effect of chemical catalysis and dielectric constant. Chem. Eng. J. 2018, 347, 447-454. [CrossRef]

13. Barakat, C.; Gravejat, P.; Guaitella, O.; Thevenet, F.; Rousseau, A. Oxidation of isopropanol and acetone adsorbed on $\mathrm{TiO}_{2}$ under plasma generated ozone flow: Gas phase and adsorbed species monitoring. Appl. Catal. B Environ. 2014, 147, 302-313. [CrossRef]

14. Xu, W.; Xu, X.; Wu, J.; Fu, M.; Chen, L.; Wang, N.; Xiao, H.; Chen, X.; Ye, D. Removal of toluene in adsorption-discharge plasma systems over a nickel modified SBA-15 catalyst. RSC Adv. 2016, 6, 104104-104111. [CrossRef]

15. Sultana, S.; Vandenbroucke, A.M.; Mora, M.; Jiménez-Sanchidrián, C.; Romero-Salguero, F.J.; Leys, C.; De Geyter, N.; Morent, R. Post plasma-catalysis for trichloroethylene decomposition over $\mathrm{CeO}_{2}$ catalyst: Synergistic effect and stability test. Appl. Catal. B Environ. 2019, 253, 49-59. [CrossRef]

16. Rivallan, M.; Fourre, E.; Aiello, S.; Tatibouet, J.M.; Thibault-Starzyk, F. Insights into the Mechanisms of Isopropanol Conversion on $\gamma-\mathrm{Al}_{2} \mathrm{O}_{3}$ by Dielectric Barrier Discharge. Plasma Process. Polym. 2012, 9, 850-854. [CrossRef] 
17. Stere, C.E.; Adress, W.; Burch, R.; Chansai, S.; Goguet, A.; Graham, W.G.; Hardacre, C. Probing a Non-Thermal Plasma Activated Heterogeneously Catalyzed Reaction Using in Situ DRIFTS-MS. ACS Catal. 2015, 5, 956-964. [CrossRef]

18. Manabe, R.; Okada, S.; Inagaki, R.; Oshima, K.; Ogo, S.; Sekine, Y. Surface Protonics Promotes Catalysis. Sci. Rep. 2016, 6, 38007. [CrossRef]

19. Sun, Y.; Li, J.; Chen, P.; Wang, B.; Wu, J.; Fu, M.; Chen, L.; Ye, D. Reverse water-gas shift in a packed bed DBD reactor: Investigation of metal-support interface towards a better understanding of plasma catalysis. Appl. Catal. A Gen. 2020, 591, 117407. [CrossRef]

20. Xu, S.; Chansai, S.; Stere, C.; Inceesungvorn, B.; Goguet, A.; Wangkawong, K.; Taylor, S.F.R.; Al-Janabi, N.; Hardacre, C.; Martin, P.A.; et al. Sustaining metal-organic frameworks for water-gas shift catalysis by non-thermal plasma. Nat. Catal. 2019, 2, 142-148. [CrossRef]

21. Xu, S.; Chansai, S.; Shao, Y.; Xu, S.; Wang, Y.-c.; Haigh, S.; Mu, Y.; Jiao, Y.; Stere, C.E.; Chen, H.; et al. Mechanistic study of non-thermal plasma assisted $\mathrm{CO}_{2}$ hydrogenation over $\mathrm{Ru}$ supported on $\mathrm{MgAl}$ layered double hydroxide. Appl. Catal. B Environ. 2020, 268, 118752. [CrossRef]

22. Kim, H.-H.; Ogata, A.; Schiorlin, M.; Marotta, E.; Paradisi, C. Oxygen Isotope $\left({ }^{18} \mathrm{O}_{2}\right)$ Evidence on the Role of Oxygen in the Plasma-Driven Catalysis of VOC Oxidation. Catal. Lett. 2010, 141, 277-282. [CrossRef]

23. Christensen, P.A.; Mashhadani, Z.T.A.W.; Md Ali, A.H.B.; Manning, D.A.C.; Carroll, M.A.; Martin, P.A. An in situ FTIR study of the plasma- and thermally-driven reaction of isopropyl alcohol at $\mathrm{CeO}_{2}$ : Evidence for a loose transition state involving $\mathrm{Ce}^{3+}$ ? PCCP 2019, 21, 1354-1366. [CrossRef] [PubMed]

24. Rodrigues, A.; Tatibouët, J.-M.; Fourré, E. Operando DRIFT Spectroscopy Characterization of Intermediate Species on Catalysts Surface in VOC Removal from Air by Non-thermal Plasma Assisted Catalysis. Plasma Chem. Plasma Process. 2016, 36, 901-915. [CrossRef]

25. Jia, Z.; Wang, X.; Thevenet, F.; Rousseau, A. Dynamic probing of plasma-catalytic surface processes: Oxidation of toluene on $\mathrm{CeO}_{2}$. Plasma Process. Polym. 2017, 14, 1600114. [CrossRef]

26. Jia, Z.; Rousseau, A. Sorbent track: Quantitative monitoring of adsorbed VOCs under in-situ plasma exposure. Sci. Rep. 2016, 6, 31888. [CrossRef]

27. Jia, Z.; Vega-González, A.; Amar, M.B.; Hassouni, K.; Tieng, S.; Touchard, S.; Kanaev, A.; Duten, X. Acetaldehyde removal using a diphasic process coupling a silver-based nano-structured catalyst and a plasma at atmospheric pressure. Catal. Today 2013, 208, 82-89. [CrossRef]

28. Sauce, S.; Vega-González, A.; Jia, Z.; Touchard, S.; Hassouni, K.; Kanaev, A.; Duten, X. New insights in understanding plasma-catalysis reaction pathways: Study of the catalytic ozonation of an acetaldehyde saturated $\mathrm{Ag} / \mathrm{TiO}_{2} / \mathrm{SiO}_{2}$ catalyst. Eur. Phys. J. Appl. Phys. 2015, 71, 20805. [CrossRef]

29. Klett, C.; Duten, X.; Tieng, S.; Touchard, S.; Jestin, P.; Hassouni, K.; Vega-González, A. Acetaldehyde removal using an atmospheric non-thermal plasma combined with a packed bed: Role of the adsorption process. J. Hazard. Mater. 2014, 279C, 356-364. [CrossRef]

30. Mann, A.K.P.; Wu, Z.; Calaza, F.C.; Overbury, S.H. Adsorption and Reaction of Acetaldehyde on Shape-Controlled $\mathrm{CeO}_{2}$ Nanocrystals: Elucidation of Structure-Function Relationships. ACS Catal. 2014, 4, 2437-2448. [CrossRef]

31. Singh, M.; Zhou, N.; Paul, D.K.; Klabunde, K.J. IR spectral evidence of aldol condensation: Acetaldehyde adsorption over $\mathrm{TiO}_{2}$ surface. J. Catal. 2008, 260, 371-379. [CrossRef]

32. Idriss, H.; Diagne, C.; Hindermann, J.P.; Kiennemann, A.; Barteau, M.A. Reactions of Acetaldehyde on $\mathrm{CeO}_{2}$ and $\mathrm{CeO}_{2}$-supported catalysts. J. Catal. 1995, 155, 219-237. [CrossRef]

33. Rekoske, J.E.; Barteau, M.A. Competition between Acetaldehyde and Crotonaldehyde during Adsorption and Reaction on Anatase and Rutile Titanium Dioxide. Langmuir ACS J. Surf. Colloids 1999, 15, 11. [CrossRef]

34. Ordomsky, V.V.; Sushkevich, V.L.; Ivanova, I.I. Study of acetaldehyde condensation chemistry over magnesia and zirconia supported on silica. J. Mol. Catal. A Chem. 2010, 333, 85-93. [CrossRef]

35. Natal Santiago, M.A.; Hill, J.S.; Dumesic, J.A. Studies of the adsorption of acetaldehyde, methyl acetate, ethyl acetate, and methyl trifluoroacetate on silica. J. Mol. Catal. A Chem. 1999, 140, 16. [CrossRef]

36. Finkelstein-Shapiro, D.; Buchbinder, A.M.; Vijayan, B.; Bhattacharyya, K.; Weitz, E.; Geiger, F.M.; Gray, K.A. Identification of Binding Sites for Acetaldehyde Adsorption on Titania Nanorod Surfaces Using CIMS. Langmuir ACS J. Surf. Colloids 2011, 27, 14842-14848. [CrossRef] [PubMed]

37. Raskó, J.; Kiss, J. Adsorption and surface reactions of acetaldehyde on alumina-supported noble metal catalysts. Catal. Lett. 2005, 101, 71-77. [CrossRef] 
38. Chang, C.-A.; Ray, B.; Paul, D.K.; Demydov, D.; Klabunde, K.J. Photocatalytic reaction of acetaldehyde over $\mathrm{SrTiO}_{3}$ nanoparticles. J. Mol. Catal. A Chem. 2008, 281, 99-106. [CrossRef]

39. Young, Z.D.; Hanspal, S.; Davis, R.J. Aldol Condensation of Acetaldehyde over Titania, Hydroxyapatite, and Magnesia. ACS Catal. 2016, 6, 3193-3202. [CrossRef]

40. Hauchecorne, B.; Terrens, D.; Verbruggen, S.; Martens, J.A.; Van Langenhove, H.; Demeestere, K.; Lenaerts, S. Elucidating the photocatalytic degradation pathway of acetaldehyde: An FTIR in situ study under atmospheric conditions. Appl. Catal. B Environ. 2011, 106, 630-638. [CrossRef]

41. Zaki, M.I.; Hasan, M.A.; Pasupulety, L. Surface Reactions of Acetone on $\mathrm{Al}_{2} \mathrm{O}_{3}, \mathrm{TiO}_{2}, \mathrm{ZrO}_{2}$, and $\mathrm{CeO}_{2}$ : IR Spectroscopic Assessment of Impacts of the Surface Acid-Base Properties. Langmuir ACS J. Surf. Colloids 2001, 17, 768-774. [CrossRef]

42. Wang, W.; Xu, D.; Cheng, B.; Yu, J.; Jiang, C. Hybrid carbon@ $\mathrm{TiO}_{2}$ hollow spheres with enhanced photocatalytic $\mathrm{CO}_{2}$ reduction activity. J. Mater. Chem. A 2017, 5, 5020-5029. [CrossRef]

43. Kasimayan, U.; Nadarajan, A.; Singaravelu, C.M.; Pan, G.T.; Kandasamy, J.; Yang, T.C.; Lin, J.H. In-situ DRIFT investigation of photocatalytic reduction and oxidation properties of $\mathrm{SiO}_{2} @ a l p h a-\mathrm{Fe}_{2} \mathrm{O}_{3}$ core-shell decorated RGO nanocomposite. Sci. Rep. 2020, 10, 2128. [CrossRef] [PubMed]

44. Yu, Z.; Chuang, S. In situ IR study of adsorbed species and photogenerated electrons during photocatalytic oxidation of ethanol on $\mathrm{TiO}_{2}$. J. Catal. 2007, 246, 118-126. [CrossRef]

45. Lukaski, A.C.; Muggli, D.S. Photocatalytic oxidation of methyl formate on $\mathrm{TiO}_{2}$ : A transient DRIFTS study. J. Catal. 2004, 223, 250-261. [CrossRef]

46. Backes, M.J.; Lukaski, A.C.; Muggli, D.S. Active sites and effects of $\mathrm{H}_{2} \mathrm{O}$ and temperature on the photocatalytic oxidation of ${ }^{13} \mathrm{C}$-acetic acid on $\mathrm{TiO}_{2}$. Appl. Catal. B Environ. 2005, 61, 21-35. [CrossRef]

47. Chuang, C.-C.; Wu, W.-C.; Huang, M.-C.; Huang, I.-C.; Lin, J.-L. FTIR Study of Adsorption and Reactions of Methyl Formate on Powdered $\mathrm{TiO}_{2}$. J. Catal. 1999, 185, 12. [CrossRef]

48. Coronado, J.M.; Kataoka, S.; Tejedor-Tejedor, I.; Anderson, M.A. Dynamic phenomena during the photocatalytic oxidation of ethanol and acetone over nanocrystalline $\mathrm{TiO}_{2}$ : Simultaneous FTIR analysis of gas and surface species. J. Catal. 2003, 219, 219-230. [CrossRef]

49. Gazsi, A.; Koós, A.; Bánsági, T.; Solymosi, F. Adsorption and decomposition of ethanol on supported Au catalysts. Catal. Today 2011, 160, 70-78. [CrossRef]

50. Liao, L.-F.; Lien, C.-F.; Lin, J.-L. FTIR study of adsorption and photoreactions of acetic acid on $\mathrm{TiO}_{2}$. Phys. Chem. Chem. Phys. 2001, 3, 7. [CrossRef]

51. Bratož, S.; Hadži, D.; Sheppard, N. The infra-red absorption bands associated with the COOH and COOD groups in dimeric carboxylic acid-II: The region from 3700 to $1500 \mathrm{~cm}^{-1}$. Spectrochim. Acta 1956, 8, $249-261$. [CrossRef]

52. Raskó, J. Adsorption and reaction of formaldehyde on $\mathrm{TiO}_{2}$-supported Rh catalysts studied by FTIR and mass spectrometry. J. Catal. 2004, 226, 183-191. [CrossRef]

53. Idriss, H.; Kim, K.S.; Barteau, M.A. Surface-dependent pathways for formaldehyde oxidation and reduction on $\mathrm{TiO}_{2}$ (001). Surf. Sci. 1992, 262, 113-127. [CrossRef]

54. Tóth, M.; Varga, E.; Oszkó, A.; Baán, K.; Kiss, J.; Erdőhelyi, A. Partial oxidation of ethanol on supported Rh catalysts: Effect of the oxide support. J. Mol. Catal. A Chem. 2016, 411, 377-387. [CrossRef]

55. Hernández-Alonso, M.D.; Tejedor-Tejedor, I.; Coronado, J.M.; Anderson, M.A.; Soria, J. Operando FTIR study of the photocatalytic oxidation of acetone in air over $\mathrm{TiO}_{2}-\mathrm{ZrO}_{2}$ thin films. Catal. Today 2009, 143, $364-373$. [CrossRef]

56. Silva, A.; Barandas, A.; Costa, L.; Borges, L.; Mattos, L.; Noronha, F. Partial oxidation of ethanol on $\mathrm{Ru} / \mathrm{Y}_{2} \mathrm{O}_{3}$ and $\mathrm{Pd} / \mathrm{Y}_{2} \mathrm{O}_{3}$ catalysts for hydrogen production. Catal. Today 2007, 129, 297-304. [CrossRef]

57. Gazsi, A.; Schubert, G.; Pusztai, P.; Solymosi, F. Photocatalytic decomposition of formic acid and methyl formate on $\mathrm{TiO}_{2}$ doped with $\mathrm{N}$ and promoted with Au. Production of $\mathrm{H}_{2}$. Int. J. Hydrogen Energy 2013, 38, 7756-7766. [CrossRef]

58. Araña, J.; Garriga i Cabo, C.; Doña-Rodríguez, J.M.; González-Díaz, O.; Herrera-Melián, J.A.; Pérez-Peña, J. FTIR study of formic acid interaction with $\mathrm{TiO}_{2}$ and $\mathrm{TiO}_{2}$ doped with $\mathrm{Pd}$ and $\mathrm{Cu}$ in photocatalytic processes. Appl. Surf. Sci. 2004, 239, 60-71. [CrossRef]

59. Miller, K.L.; Lee, C.W.; Falconer, J.L.; Medlin, J.W. Effect of water on formic acid photocatalytic decomposition on $\mathrm{TiO}_{2}$ and $\mathrm{Pt} / \mathrm{TiO}_{2}$. J. Catal. 2010, 275, 294-299. [CrossRef] 
60. Liao, L.-F.; Wu, W.-C.; Chen, C.-Y.; Lin, J.-L. Photooxidation of Formic Acid vs. Formate and Ethanol vs. Ethoxy on $\mathrm{TiO}_{2}$ and Effect of Adsorbed Water on the Rates of Formate and Formic Acid Photooxidation. J. Phys. Chem. B 2001, 105, 7678-7685. [CrossRef]

61. Li, C.; Domen, K.; Maruya, K.; Onishi, T. Spectroscopic Identification of Adsorbed Species Derived from Adsorption and Decomposition of Formic Acid, Methanol, and Formaldehyde on Cerium Oxide. J. Catal. 1990, 125, 11. [CrossRef]

62. Xie, B.; Wong, R.J.; Tan, T.H.; Higham, M.; Gibson, E.K.; Decarolis, D.; Callison, J.; Aguey-Zinsou, K.F.; Bowker, M.; Catlow, C.R.A.; et al. Synergistic ultraviolet and visible light photo-activation enables intensified low-temperature methanol synthesis over copper/zinc oxide/alumina. Nat. Commun. 2020, 11, 1615. [CrossRef] [PubMed]

63. Sadykov, V.A.; Eremeev, N.F.; Sadovskaya, E.M.; Chesalov, Y.A.; Pavlova, S.N.; Rogov, V.A.; Simonov, M.N.; Bobin, A.S.; Glazneva, T.S.; Smal, E.A.; et al. Detailed Mechanism of Ethanol Transformation into Syngas on Catalysts Based on Mesoporous $\mathrm{MgAl}_{2} \mathrm{O}_{4}$ Support Loaded with $\mathrm{Ru}+\mathrm{Ni} /\left(\mathrm{PrCeZrO}\right.$ or $\left.\mathrm{MnCr}_{2} \mathrm{O}_{4}\right)$ Active Components. Top. Catal. 2020, 63, 166-177. [CrossRef]

64. Topalian, Z.; Stefanov, B.I.; Granqvist, C.G.; Österlund, L. Adsorption and photo-oxidation of acetaldehyde on $\mathrm{TiO}_{2}$ and sulfate-modified $\mathrm{TiO}_{2}$ : Studies by in situ FTIR spectroscopy and micro-kinetic modeling. J. Catal. 2013, 307, 265-274. [CrossRef]

65. Raskó, J.; Kecskés, T.; Kiss, J. FT-IR and mass spectrometric studies on the interaction of acetaldehyde with $\mathrm{TiO}_{2}$-supported noble metal catalysts. Appl. Catal. A Gen. 2005, 287, 244-251. [CrossRef]

66. Idriss, H.; Kim, K.S.; Barteau, M.A. Carbon-Carbon Bond Formation via Aldolization of Acetaldehyde on Single Crystal and Polycrystalline $\mathrm{TiO}_{2}$ Surfaces. J. Catal. 1993, 139, 15. [CrossRef]

67. Kim, K.S.; Barteau, M.A. Structure and Composition Requirements for Deoxygenation, Dehydration, and Ketonization Reactions of Carboxylic Acids on $\mathrm{TiO}_{2}(001)$ Single-Crystal Surfaces. J. Catal. 1990, 125, 23. [CrossRef]

68. Sheng, P.Y.; Bowmaker, G.A.; Idriss, H. The Reactions of Ethanol over Au/CeO . Appl. Catal. A Gen. 2004, 261, 171-181. [CrossRef]

69. Rorrer, J.E.; Toste, F.D.; Bell, A.T. Mechanism and Kinetics of Isobutene Formation from Ethanol and Acetone over $\mathrm{Zn}_{\mathrm{x}} \mathrm{Zr}_{\mathrm{y}} \mathrm{O}_{\mathrm{z}}$. ACS Catal. 2019, 9, 10588-10604. [CrossRef]

70. Velasquez Ochoa, J.; Farci, E.; Cavani, F.; Sinisi, F.; Artiglia, L.; Agnoli, S.; Granozzi, G.; Paganini, M.C.; Malfatti, $\mathrm{L} . \mathrm{CeO}_{x} / \mathrm{TiO}_{2}$ (Rutile) Nanocomposites for the Low-Temperature Dehydrogenation of Ethanol to Acetaldehyde: A Diffuse Reflectance Infrared Fourier Transform Spectroscopy-Mass Spectrometry Study. ACS Appl. Nano Mater. 2019, 2, 3434-3443. [CrossRef]

71. Bokhimi, X.; Zanella, R.; Maturano, V.; Morales, A. Nanocrystalline Ag, and Au-Ag alloys supported on titania for CO oxidation reaction. Mater. Chem. Phys. 2013, 138, 490-499. [CrossRef]

72. Zhao, D.Z.; Shi, C.; Li, X.S.; Zhu, A.M.; Jang, B.W. Enhanced effect of water vapor on complete oxidation of formaldehyde in air with ozone over $\mathrm{MnO}_{\mathrm{x}}$ catalysts at room temperature. J. Hazard. Mater. 2012, 239-240, 362-369. [CrossRef] [PubMed]

73. Nie, L.; Yu, J.; Jaroniec, M.; Tao, F.F. Room-temperature catalytic oxidation of formaldehyde on catalysts. Catal. Sci. Technol. 2016, 6, 3649-3669. [CrossRef]

74. Sun, Z.; Zhang, X.; Li, H.; Liu, T.; Sang, S.; Chen, S.; Duan, L.; Zeng, L.; Xiang, W.; Gong, J. Chemical looping oxidative steam reforming of methanol: A new pathway for auto-thermal conversion. Appl. Catal. B Environ. 2020, 269, 118758. [CrossRef]

75. Manzoli, M.; Chiorino, A.; Boccuzzi, F. Decomposition and combined reforming of methanol to hydrogen: A FTIR and QMS study on $\mathrm{Cu}$ and $\mathrm{Au}$ catalysts supported on $\mathrm{ZnO}$ and $\mathrm{TiO}_{2}$. Appl. Catal. B Environ. 2005, 57, 201-209. [CrossRef]

76. Han, Y.; Liu, C.-J.; Ge, Q. Effect of Pt Clusters on Methanol Adsorption and Dissociation over Perfect and Defective Anatase $\mathrm{TiO}_{2}$ (101) Surface. J. Phys. Chem. C 2009, 113, 20674-20682. [CrossRef]

77. Wittstock, A.; Zielasek, V.; Biener, J.; Friend, C.M.; Bäumer, M. Nanoporous Gold Catalysts for Selective Gas-Phase Oxidative Coupling of Methanol at Low Temperature. Science 2010, 327, 319. [CrossRef]

78. Klett, C.; Touchard, S.; Vega-González, A.; Redolfi, M.; Bonnin, X.; Hassouni, K.; Duten, X. Experimental and modeling study of the oxidation of acetaldehyde in an atmospheric-pressure pulsed corona discharge. Plasma Sources Sci. Technol. 2012, 21, 045001. [CrossRef] 
79. Yang, Z.; Li, J.; Yang, X.; Wu, Y. Catalytic oxidation of methanol to methyl formate over silver? A new purpose of a traditional catalysis system. Catal. Lett. 2005, 100, 205-211. [CrossRef]

80. Rebsdat, S.; Mayer, D.; Ethylene Oxide. Ethylene Oxide. In Ullmann's Encyclopedia of Industrial Chemistry; Wiley-VCH Verlag GmbH \& Co: Weinheim, Germany, 2001. Available online: https://onlinelibrary.wiley. com/doi/abs/10.1002/14356007.a10_117 (accessed on 28 July 2020).

81. Li, Y.; Yue, B.; Yan, S.; Yang, W.; Xie, Z.; Chen, Q.; He, H. Preparation of Ethylene Glycol via Catalytic Hydration with Highly Efficient Supported Niobia Catalyst. Catal. Lett. 2004, 95, 163-166. [CrossRef]

82. Kandasamy, S.; Samudrala, S.P.; Bhattacharya, S. The route towards sustainable production of ethylene glycol from a renewable resource, biodiesel waste: A review. Catal. Sci. Technol. 2019, 9, 567-577. [CrossRef]

83. Yu, W.; Mellinger, Z.J.; Barteau, M.A.; Chen, J.G. Comparison of Reaction Pathways of Ethylene Glycol, Acetaldehyde, and Acetic Acid on Tungsten Carbide and Ni-Modified Tungsten Carbide Surfaces. J. Phys. Chem. C 2012, 116, 5720-5729. [CrossRef]

84. McManus, J.R.; Martono, E.; Vohs, J.M. Selective Deoxygenation of Aldehydes: The Reaction of Acetaldehyde and Glycolaldehyde on Zn/Pt(111) Bimetallic Surfaces. ACS Catal. 2013, 3, 1739-1750. [CrossRef]

85. Neitzel, A.; Lykhach, Y.; Johánek, V.; Tsud, N.; Skála, T.; Prince, K.C.; Matolín, V.; Libuda, J. Role of Oxygen in Acetic Acid Decomposition on Pt(111). J. Phys. Chem. C 2014, 118, 14316-14325. [CrossRef]

86. Chang, Y.-C.; Ko, A.-N. Vapor phase reactions of acetaldehyde over type X zeolites. Appl. Catal. A Gen. 2000, 190, 149-155. [CrossRef]

87. Boamah, M.D.; Sullivan, K.K.; Shulenberger, K.E.; Soe, C.M.; Jacob, L.M.; Yhee, F.C.; Atkinson, K.E.; Boyer, M.C.; Haines, D.R.; Arumainayagam, C.R. Low-energy electron-induced chemistry of condensed methanol: Implications for the interstellar synthesis of prebiotic molecules. Faraday Discuss. 2014, 168, 249. [CrossRef] [PubMed]

88. Busca, G. Infrared studies of the reactive adsorption of organic molecules over metal oxides and of the mechanisms of their heterogeneously-catalyzed oxidation. Catal. Today 1996, 27, 40. [CrossRef]

89. Kim, M.; Park, E.; Jurng, J. Oxidation of gaseous formaldehyde with ozone over $\mathrm{MnO}_{\mathrm{x}} / \mathrm{TiO}_{2}$ catalysts at room temperature $\left(25^{\circ} \mathrm{C}\right)$. Powder Technol. 2018, 325, 368-372. [CrossRef]

90. Wittstock, A.; Biener, J.; Bäumer, M. Nanoporous Gold: A Novel Catalyst with Tunable Properties. ECS Trans. 2010, 28, 1-13. [CrossRef]

91. Jia, Z.; Ben Amar, M.; Brinza, O.; Astafiev, A.; Nadtochenko, V.; Evlyukhin, A.B.; Chichkov, B.N.; Duten, X.; Kanaev, A. Growth of Silver Nanoclusters on Monolayer Nanoparticulate Titanium-oxo-alkoxy Coatings. J. Phys. Chem. C 2012, 116, 17239-17247. [CrossRef] 